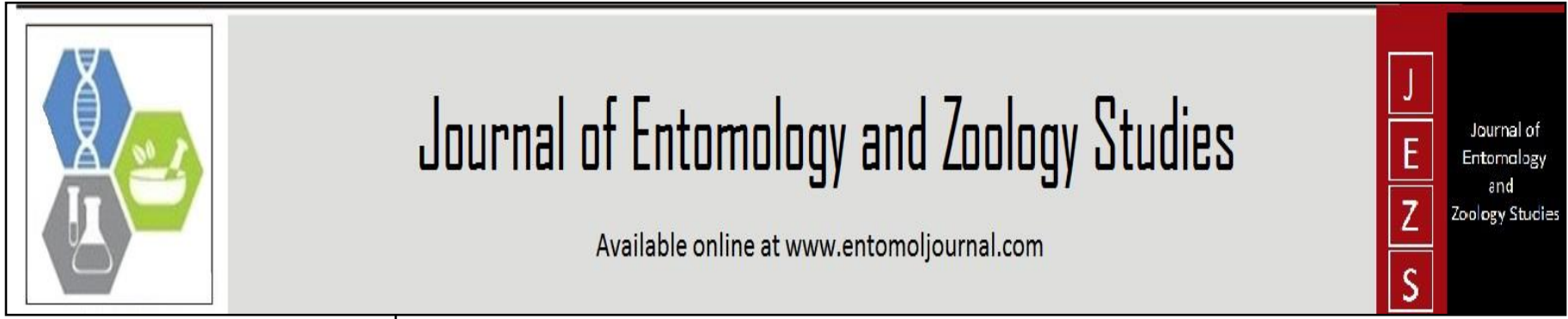

E-ISSN: 2320-7078

P-ISSN: 2349-6800

www.entomoljournal.com

JEZS 2020; 8(6): 1905-1908

(C) $2020 \mathrm{JEZS}$

Received: 08-09-2020

Accepted: 13-10-2020

\section{Anannya Das}

M.V.Sc Scholar, Department of Livestock Products Technology, College Of Veterinary Sciences and Animal Husbandry, Central Agricultural University(CAU),

Selesih, Aizawl, Mizoram, India

Pragati Hazarika

Department of Livestock

Products Technology, College of

Veterinary Sciences and Animal

Husbandry, Central Agricultural

University (CAU), Selesih,

Aizawl, Mizoram, India

\section{Lallawmzuali Ralte}

Department of Livestock

Products Technology, College of

Veterinary Sciences and Animal

Husbandry, Central Agricultural

University (CAU), Selesih,

Aizawl, Mizoram, India

Jitendra Kumar Choaudhury

Department of Livestock

Products Technology, College of

Veterinary Sciences and Animal

Husbandry, Central Agricultural

University (CAU), Selesih,

Aizawl, Mizoram, India

Keshab Dabnath

Department of Livestock

Products Technology, College of

Veterinary Sciences and Animal

Husbandry, Central Agricultural

University (CAU), Selesih,

Aizawl, Mizoram, India

\section{Sandeep Kumar}

Department of Livestock

Products Technology, College of

Veterinary Sciences and Animal

Husbandry, Central Agricultural

University (CAU), Selesih,

Aizawl, Mizoram, India

Corresponding Author:

Anannya Das

M.V.Sc Scholar, Department of

Livestock Products Technology,

College Of Veterinary Sciences

and Animal Husbandry, Central

Agricultural University(CAU),

Selesih, Aizawl, Mizoram, India

\section{Effect of oatmeal and oyster mushroom on the quality and sensory characteristics of pork momo}

\author{
Anannya Das, Pragati Hazarika, Lallawmzuali Ralte, Jitendra Kumar \\ Choaudhury, Keshab Dabnath and Sandeep Kumar
}

DOI: https://doi.org/10.22271/j.ento.2020.v8.i6z.8101

\section{Abstract}

Consumption of unhealthy snack food with low nutritive value is one of the predisposing factors for most of the metabolic diseases. So, it is require to develop a ready-to-eat shelf stable meat product. Therefore, this research work has been focused on formulation of shelf-stable pork momo. Pork momo recipe was formulated and allotted into two different treatment group, viz. Treatment 1(pork momo with olive oil and oatmeal) and Treatment 2(pork momo with olive oil and dried oyster mushroom) and stored in domestic refrigerator. A gradual increase in the mean $\mathrm{pH}, \mathrm{TV}$, TBA number of $\mathrm{T} 1$ and $\mathrm{T} 2$ were observed with the advancement of storage periods, which differs significantly $(p \leq 0.001)$ on the $0,5^{\text {th }}, 7^{\text {th }}, 10^{\text {th }}$ and $12^{\text {th }}$ day of storage study. The rate of increase was more pronounced in the samples T1 than T2. Sensory scores for appearance, flavour, texture, juiciness and overall acceptability were significantly higher in T2. So, the combined use of olive oil and dried oyster mushroom for development of healthy pork momo was successfully attempted as superior in physico-chemical and sensory attributes.

Keywords: Ready-to-eat meal, pork momo, dried oyster mushroom, sensory quality

\section{Introduction}

In recent years, the consumption of snacks has been increase considerably due to the changing life style of the people. In India snack foods market has achieved rs.1530 corers which expected to grow from 9 to $12 \%$ during tenth five-year plan ${ }^{[21]}$. The snacks, prepared by reformulating with vegetables ingredients are available in the market can met the demand of consumer's acceptability. Momo(s), a well-known snacks food is one of the most unique and delicious fast food items which are available in different types of stuffing. The filling may be one of the several mixtures of minced chicken/beef/ pork/ or vegetables with condiments. The demand of R-T-E meat product increased in recent years because of convenience and the reduction making time. So, the increased demand for quality meat and RTE meat products has been resulted in the development of meat products by incorporation of non-meat ingredients in the formulation. Pork and organ meats are good source of Linoleic. Acid and Linolenic acid and contains several bioactive peptides and nutraceutical substances, which have good impact on health ${ }^{[8]}$. The utilization of vegetable oils in low fat meat products as a fat-replacer helps to prolong the storage stability by lowering the oxidation of lipids, free fatty acids, peroxide values. Dietary fiber can be incorporated in meat and meat based products via many sources like vegetables, fruit, legumes, cereals, etc. in the form of extenders, fillers, binders, that increase the profit margins of the food industries. Oatmeal had gained a very positive consumer image because high fiber and low fat content ${ }^{[20]}$. Oyster mushroom is the commercially important edible famous mushroom for its delicious taste and high quantities of proteins, carbohydrates, minerals and vitamins as well as low fat ${ }^{[1]}$.

\section{Materials and Methods}

\section{Preparation of meat product}

Meaty cuts (ham) were purchased from the freshly slaughtered Yorkshire pig carcass and edible olive oil, oatmeal and oyster mushroom (OM) were also purchased from the local market of Aizawl. The meaty cuts were processed in the Department of Livestock Products Technology. After proper washing the meaty cuts were pressure cooked at $121^{\circ} \mathrm{C}$ for 25 minutes. After that the bones and visible fats were removed manually and were cut into small chunks in order to mince it. The pieces of $\mathrm{OM}$ were dried in hot air oven at $70^{\circ} \mathrm{C}$ for overnight. Both the oatmeal and $\mathrm{OM}$ were ground in the mixture grinder. 
The onion and ginger were peeled off and the dough was prepared by using refined wheat flour; stuffing material was placed into center of dough to cover the momo and steam cooked up to 30 minutes. The different type's pork momo, prepared by using ingredients mixture as shown in Table: 1. The samples were packed aerobically in low density polyethylene bags (LDPE) and kept in domestic refrigerator $\left(4 \pm 1^{\circ} \mathrm{C}\right)$ for 12 days and analyzed for different physicchemical and sensory parameters at a periodic interval

Table 1: Formulation for the preparation of different treatment of pork momo.

\begin{tabular}{|c|c|c|}
\hline Ingredients & Treatment 1 & Treatment 2 \\
\hline Pork & $70 \%$ & $.70 \%$ \\
\hline Olive oil & $5 \%$ & $5 \%$ \\
\hline Oatmeal & $15 \%$ & $\overline{15 \%}$ \\
\hline $\begin{array}{c}\text { Dried Oyster Mushroom } \\
\text { Condiments (onion : ginger in } 4: 1 \\
\text { ratio) }\end{array}$ & $8 \%$ & $8 \%$ \\
\hline Common salt & $2 \%$ & $2 \%$ \\
\hline
\end{tabular}

\section{Physico-chemical parameters}

$\mathrm{pH}$ of the samples was determined by using a $\mathrm{pH}$ meter (Cyberscan 1000 Euteoh instruments) and by following the method of ${ }^{[2]}$ on $0,5^{\text {th }}, 7^{\text {th }}, 10^{\text {th }}, 12^{\text {th }}$ day of refrigeration storage.

Tyrosine value (TV) and Thiobarbituric acid number (TBA) number

TV and TBA number were determined in the spectrophotometer by following the method of [22] and [25] respectively.

\section{Sensory evaluation of stored samples}

Standard sensory evaluation method using an 8 point hedonic scale [11] was followed with slight modification, where $8=$ excellent, $1=$ extremely poor, warm samples were serve to the panelists and water was provided to rinse the mouth between the samples. The panelist judged the products for general appearance, flavor, juiciness, texture and overall palatability using the score card for all the samples during the refrigeration storage days.

\section{Statistical Analysis}

General Linear Model of two ways ANOVA based on Fisher's Least Significant Difference method was used to determine the significant difference among days for different treatment groups as well as among groups. Non-parametric test Kruskal Walis test has been used to determine the significant difference among days as well as among treatments for ranking observations. The significant values in the ANOVA were further tested through Duncan multiple range test. The data obtained were analysed using statistical package SPSS version 25.00. Results are delineated as Mean \pm S.E when $p \leq 0.005, p \leq 0.001$ and $\mathrm{p}=0.000$ then the difference were considered as significant.

\section{Results and discussion \\ Physico- chemical quality}

Results presented in the Table 2 showed that $\mathrm{pH}$ value of pork momo increased gradually as the storage period enhances. The differences in $\mathrm{pH}$ value might have occurred due to the several factors like decomposition, releasing of amino acid in the meat, and liberation of calcium and magnesium ions from proteins ${ }^{[15]}$. The $\mathrm{pH}$ value was decreased significantly $(p \leq 0.001)$ in $\mathrm{T} 2$ than that of $\mathrm{T} 1$ sample. It may be due to the use of oyster mushroom in $\mathrm{T} 2$ which inhibits the growth of microorganism as it has a good source of antioxidant ${ }^{[5]}$. The TBA number was gradually elevated from 0 day to $12^{\text {th }}$ day of storage which was highly significant in case of all the treatment. Similar trend of increased of TBA values also reported ${ }^{[6]}$. The increased TBA value throughout the storage period might be due to the oxidation of fatty acids and production of volatile metabolites in the presence of oxygen during aerobic packaging of pork momo ${ }^{[9]}$. The TBA number is used as an indicator of food quality which is highly related to rancidity. Among all this two samples, it has been observed that T2 had shown the lowest oxidation, because of the presence of oyster mushroom in the formulation. This result clearly revealed that the phenolic compounds of oyster mushroom reduce the oxidation level compare to T1. Similar kind of strong reducing power and high antioxidant activity of mushroom extract, leads to inhibition of the lipid oxidation, was stated by ${ }^{[4]}$ in their study in beef and fish meats. The TV has significantly increased on the advancement of storage period of samples. Similar finding was reported by ${ }^{[24]}$. The increased TV might be due to increased microbial load which leads to the production of proteolytic enzymes in the logarithm of bacterial growth phase which resulted into autolysis and bacterial proteolysis ${ }^{[13]}$. The sample of T2 showed less increase of $\mathrm{TV}$ than $\mathrm{T} 1$ during subsequent storage periods, as because of $\mathrm{T} 2$ contains oyster mushroom which has a good source of antioxidant. Oyster Mushroom has been shown to have a distinctive amount of Ergothioneine [3] which can suppress the oxidation process and this way reduce the increase of TV of the sample.

Table 2: Physico-chemical properties of pork momo (LDPE packaged) under refrigeration storage at $4 \pm 1{ }^{\circ} \mathrm{C}$

\begin{tabular}{|c|c|c|c|c|c|c|}
\hline \multicolumn{7}{|c|}{ pH } \\
\hline \multirow{2}{*}{ Treatment Groups } & \multicolumn{6}{|c|}{ Period of storage (days) } \\
\hline & $\mathbf{0}$ & 5 & 7 & 10 & \multicolumn{2}{|c|}{12} \\
\hline $\mathrm{T} 1$ & $6.40 \pm 0.007^{\mathrm{aC}}$ & $6.43 \pm 0.007^{\mathrm{bC}}$ & $6.47 \pm 0.006^{\mathrm{cC}}$ & $6.50 \pm 0.008^{\mathrm{d}} \mathrm{C}$ & \multicolumn{2}{|c|}{$6.54 \pm 0.008^{\mathrm{eC}}$} \\
\hline \multirow[t]{2}{*}{$\mathrm{T} 2$} & $6.35 \pm 0.008^{\mathrm{aB}}$ & $6.38 \pm 0.004^{\mathrm{bB}}$ & $6.40 \pm 0.006^{\mathrm{bB}}$ & $6.45 \pm 0.005^{\mathrm{cB}}$ & $6.50 \pm 0$ & $.005^{\mathrm{dB}}$ \\
\hline & \multicolumn{6}{|c|}{ TV(mg tyrosine/ 100g) } \\
\hline \multirow{2}{*}{ Treatment Groups } & \multicolumn{6}{|c|}{ Period of storage (days) } \\
\hline & $\mathbf{0}$ & 5 & 7 & 10 & \multicolumn{2}{|c|}{12} \\
\hline $\mathrm{T} 1$ & $0.538 \pm 0.006^{\mathrm{aAB}}$ & $0.551 \pm 0.009^{\mathrm{abA}}$ & $0.560 \pm 0.005^{\mathrm{bA}}$ & $0.620 \pm 0.005^{\mathrm{cA}}$ & \multicolumn{2}{|c|}{$0.640 \pm 0.005^{\mathrm{dA}}$} \\
\hline \multirow[t]{3}{*}{$\mathrm{T} 2$} & $0.555 \pm 0.007^{\mathrm{aBC}}$ & $0.586 \pm 0.006^{\mathrm{bB}}$ & $0.605 \pm 0.007^{\mathrm{bB}}$ & $0.648 \pm 0.006^{\mathrm{cB}}$ & $0.688 \pm$ & $.009^{\mathrm{cB}}$ \\
\hline & \multicolumn{6}{|c|}{ TBA(mg malonaldehyde/kg) } \\
\hline & \multicolumn{6}{|c|}{ Period of storage (days) } \\
\hline Treatment Groups & \multicolumn{2}{|c|}{$\begin{array}{c}\mathbf{0} \\
0.538+0.006^{\mathrm{aAB}}\end{array}$} & 5 & 7 & 10 & 12 \\
\hline $\mathrm{T} 1$ & & & $0.551 \pm 0.009^{\mathrm{abA}}$ & $0.560 \pm 0.005^{\mathrm{bA}}$ & $0.620 \pm 0.005^{\mathrm{cA}}$ & $0.640 \pm 0.005^{\mathrm{dA}}$ \\
\hline $\mathrm{T} 2$ & \multicolumn{2}{|c|}{$0.555 \pm 0.007^{\mathrm{aBC}}$} & $0.586 \pm 0.006^{\mathrm{bB}}$ & $0.605 \pm 0.007^{\mathrm{bB}}$ & $0.648 \pm 0.006^{\mathrm{cB}}$ & $0.688 \pm 0.009^{\mathrm{cB}}$ \\
\hline
\end{tabular}

Note: $\mathrm{n}=6,{ }^{* *}$ Significant at $1 \%(p \leq 0.01),{ }^{*}$ Significant at $5 \%(p \leq 0.05)$, NS-Non significant between the columns and rows. Same superscripts (upper case) along a column do not differ significantly and same superscripts (lower case) along the row do not differ significantly 


\section{Sensory evaluation}

The sensory qualities such as appearance, flavour, texture, juiciness and overall acceptability of cooked and stored samples were decreases with increased storage periods. The samples of Treatment 1 and 2, although could be stored up to $12^{\text {th }}$ day of refrigeration storage yet this product reaches their threshold level in terms of appearance, flavour, texture, juiciness and overall acceptability especially on the $12^{\text {th }}$ day of storage. The T2 sample was scored the higher panel ratings in terms of appearance, flavor, texture, juiciness and overall acceptability than $\mathrm{T} 1$ sample. The declined in appearance score might be due to surface drying or lipid and protein [7], the decreases of appearance score of meat product with increase of storage period was reported by ${ }^{[23]}$. Increased storage time was leads to reduction of flavor scores ${ }^{[15]}$. This reduction was may be due to oxidative rancidity of the fatty acids of the product and increased microbial load ${ }^{[18]}$. The Texture score also significantly decreased during storage days. It might be due to dehydration of cooked samples resulting hardening texture and breakdown of protein. The findings were supported by ${ }^{[12]}$. The significant decrease in texture was due to changes in the disulphide bond and contents of amino acid ${ }^{[19]}$. As storage time increases, results in reduction of juiciness scores. This result was also supported by ${ }^{[10]}$. The advancement of storage periods leads to reduction of juiciness and texture in chicken sausage ${ }^{[26]}$. The reason for reduced juiciness scores was may be due to dehydration of the product with advancement of refrigerated storage. Overall acceptability score was reduced with the advancement of storage periods as reported by the ${ }^{[17]}$ in chicken loaves. This study revealed that highly significant $(\mathrm{p}<0.01)$ difference was observed between the treatments in terms of appearance, flavour, texture, juiciness and overall acceptability with advancement of storage period. The overall acceptability was reduce, it might be due to lipid oxidation, liberation of fatty acid, increase microbial load, loss of moisture, degradation of muscle fibre by bacterial action ${ }^{[14]}$.

Table 3: Sensory qualities of Pork Momo (LDPE packaged) under refrigeration storage at $4 \pm 1^{0} \mathrm{C}$.

\begin{tabular}{|c|c|c|c|c|c|}
\hline \multirow{3}{*}{$\begin{array}{c}\text { Treatment } \\
\text { Groups }\end{array}$} & \multicolumn{5}{|c|}{ Appearance } \\
\hline & \multicolumn{5}{|c|}{ Period of storage (days) } \\
\hline & $\mathbf{0}$ & 5 & 7 & 10 & 12 \\
\hline T1 & $7.00 \pm 0.007^{\mathrm{aC}}$ & $6.73 \pm 0.008^{\mathrm{bC}}$ & $6.52 \pm 0.007^{\mathrm{abB}}$ & $6.24 \pm 0.006^{\mathrm{cC}}$ & $6.15 \pm 0.009^{\mathrm{dC}}$ \\
\hline $\mathrm{T} 2$ & $7.33 \pm 0.008^{\mathrm{aD}}$ & $7.12 \pm 0.008^{\mathrm{bD}}$ & $7.00 \pm 0.007^{\mathrm{abC}}$ & $6.81 \pm 0.006^{\mathrm{cD}}$ & $6.52 \pm 0.007^{\mathrm{dD}}$ \\
\hline Treatment Groups & \multicolumn{5}{|c|}{ Flavor } \\
\hline T1 & $7.11 \pm 0.007^{\mathrm{aA}}$ & $6.90 \pm 0.007^{\mathrm{bC}}$ & $6.71 \pm 0.007^{\mathrm{abAB}}$ & $6.22 \pm 0.008^{\mathrm{cAB}}$ & $6.00 \pm 0.007^{\mathrm{dAB}}$ \\
\hline $\mathrm{T} 2$ & $7.31 \pm 0.007^{\mathrm{aAB}}$ & $7.04 \pm .005^{\mathrm{bD}}$ & $6.80 \pm 0.006^{\mathrm{abB}}$ & $6.71 \pm 0.007^{\mathrm{cC}}$ & $6.53 \pm 0.006^{\mathrm{dC}}$ \\
\hline Treatment Groups & \multicolumn{5}{|c|}{ Texture } \\
\hline $\mathrm{T} 1$ & $6.70 \pm 0.007^{\mathrm{aA}}$ & $6.65 \pm 0.007^{\mathrm{bB}}$ & $6.40 \pm 0.007^{\mathrm{abA}}$ & $6.28 \pm 0.007^{\mathrm{cC}}$ & $6.00 \pm 0.008^{\mathrm{dB}}$ \\
\hline $\mathrm{T} 2$ & $6.92 \pm 0.009^{\mathrm{aB}}$ & $6.85 \pm 0.005^{\mathrm{bC}}$ & $6.70 \pm 0.007^{\mathrm{abB}}$ & $6.51 \pm 0.006^{\mathrm{cD}}$ & $6.64 \pm 0.046^{\mathrm{dC}}$ \\
\hline Treatment Groups & \multicolumn{5}{|c|}{ Juiciness } \\
\hline T1 & $6.57 \pm 0.007^{\mathrm{aB}}$ & $6.50 \pm 0.007^{\mathrm{bB}}$ & $6.42 \pm 0.007^{\mathrm{abC}}$ & $6.25 \pm 0.005^{\mathrm{cB}}$ & $6.16 \pm 0.007^{\mathrm{dB}}$ \\
\hline $\mathrm{T} 2$ & $7.21 \pm 0.008^{\mathrm{aAB}}$ & $7.11 \pm 0.007^{\mathrm{bAB}}$ & $6.95 \pm 0.008^{\mathrm{cD}}$ & $6.76 \pm 0.006^{\mathrm{dAB}}$ & $6.62 \pm 0.006^{\mathrm{eC}}$ \\
\hline Treatment Groups & \multicolumn{5}{|c|}{ Overall acceptability } \\
\hline $\mathrm{T} 1$ & $7.10 \pm 0.006^{\mathrm{aB}}$ & $6.95 \pm 0.006^{\mathrm{bC}}$ & $6.60 \pm 0.007^{\mathrm{abC}}$ & $6.42 \pm 0.007^{\mathrm{cC}}$ & $6.21 \pm 0.008^{\mathrm{dC}}$ \\
\hline $\mathrm{T} 2$ & $7.25 \pm 0.006^{\mathrm{aC}}$ & $7.11 \pm 0.007^{\mathrm{bD}}$ & $7.00 \pm 0.006^{\mathrm{abD}}$ & $6.85 \pm 0.005^{\mathrm{cD}}$ & $6.70 \pm 0.007^{\mathrm{dD}}$ \\
\hline
\end{tabular}

Note: $\mathrm{n}=6,{ }^{* *}$ Significant at $1 \%(p \leq 0.01),{ }^{*}$ Significant at $5 \%(p \leq 0.05)$, NS-Non significant between the columns and rows. Same superscripts (upper case) along a column do not differ significantly and same superscripts (lower case) along the row do not differ significantly.

\section{Conclusion}

Based on the result it was concluded that the sample of T2 was found to be superior in physicochemical and sensory attributes with advanced shelf-life and the addition of $\mathrm{OM}$ at $15 \%$ level not only protected against oxidative rancidity but also had higher acceptability as OM treated pork momo usually have significantly $(P \leq 0.01)$ lower $\mathrm{pH}$, TBARS and $\mathrm{TV}$, whereas significantly $(P \leq 0.01)$ higher sensory scores throughout the storage period than oatmeal treated pork momo.

\section{Acknowledgement}

I am grateful to the Head, Department of livestock product technology, Dean of this Institute, Head of Veterinary Pharmacology, Animal Nutrition, veterinary microbiology, Veterinary Public Health and Epidemiology Department for providing me the laboratory facilities to carry out this study.

\section{Reference}

1. Al-Subhi FM. Evaluation of Mushrooms Broth Cube and Its Compared With Maggi Broth Cube Products in Saudi
Arabia. J Am Sci 2013;9(5):250-255.

2. AOAC. Official methods of analysis, $16^{\text {th }}$ edn., Association of Official analytical chemists, washington DC, 1995.

3. Aruoma OI, Whiteman M, England, TG, Halliwell B. Antioxidant action of ergothioneine: assessment of its ability to scavenge peroxynitrite. Biochemical and Biophysical Research Communications 1997;231:389391.

4. Bao HND, Ushio H, Ohshima T. Antioxidative activity and antidiscoloration efficacy of ergothioneine in mushroom (Flammulina velutipes) extract added to beef and fish meats. Journal of Agricultural and Food Chemistry 2008;56(21):10032-10040. https://doi.org/10.1021/jf8017063.

5. Barros L, Venturini BA, Baptista P, Estevinho LM, Ferreira ICFR. Chemical composition and biological properties of Portuguese wild mushrooms: a comprehensive study. J Agric Foo Chem 2008;56:385662 .

6. Biswas S, Chakraborty A, Patra G, Dhargupta A. Quality 
and acceptability of duck patties stored at ambient and refrigeration temperature. Int. J Livest. Prod 2011;2(1):001-006.

7. Che Man YB, Bakar J, Mokri AAK. Effect of packaging films on storage stability of intermediate deep fried mackerel. Inter. J Food Sci. Technol 1995;30:175-179.

8. Hazarika M, Rahman H, Hazarika D. Antimicrobial activity of fermented bamboo shoot (kharicha) extract. Assam Science Society 53 ${ }^{\text {rd }}$ Annual Technical Session, March 15, 2008. College of Veterinary Sciences, AAU, Khanapara, Gwahati-781022 Assam.

9. Jo C, Lee, JI, Ahn DU. Lipid oxidation, color changes and volatiles production in irradiated pork sausage with different fat content and packaging during storage. Meat Sci 1999;51(4):355-361.

10. Kalaikannan A, Anjaneyulu ASR, Santhi D Effect of egg proteins on the quality and refrigerated storage life of chicken patties made with broiler-spent hen meat and byproducts. International J Food Sci Technol 2007;42:579586.

11. Keeton JI. Effect of fat and Nacl/phosphate levels on the chemical and sensory properties of pork patties. J Food Sci 1983;48:878.

12. Kumar M, Sharma BD. Quality and storage stability of low-fat pork patties containing barley flour as-fat substitute. J Food Sci. Technol 2004;41(5):496-502.

13. Kumar JB, Radhakrishnan KT. Quality characteristics and shelf life of cured and smoked culled broiler chicken. Ind. J of Anim. Sci 2006;76(11):94-978.

14. Kumar L, Bhat ZF, Kumar S. Effect on nisin on quality characteristics of fiber- enriched chicken harrisa. J Meat Sci 2016;11(2):57-63.

15. Medynski A, Pospiech E, Kniat R. Effect of various concentrations of lactic acid and sodium chloride on selected physiochemical meat traits. J Meat Sci 2000;55:285-290.

16. Nath RL, Mahapatra CM, Kondaiah N, Anand SK, Singh JN. Effect of levels of chicken fat on the quality and storage life of chicken patties. Indian J Poult Sci 1995;30:52-57.

17. Reddy PK, Rao ST. Influence of binders and refrigerated storage on certain quality characteristics of chicken and duck meat patties. J Food Sci. Technol 1997;34(5):446449.

18. Sahoo J, Anjaneyulu ASR. Effect of natural antioxidants and vacuum packaging on the quality of buffalo meat nuggets during refrigerated storage. Meat Sci 1997;47(34):223-230

19. Santamaria L, Lizarraga T, Astiasaran I, Bello J. Characterization of pamplona chorizo sausages, physicochemical and sensory studies. Revists-Espanole-deCiencis-Technologis-de Alimentos 1992;32:431-445.

20. Shinnick FL, Ink SI, Marlett JA. Dose response to a dietary oat bran fraction in cholesterol-fed rats. Journal of Nutrition 1990;120:561-568.

21. Singh P, Sahoo J, Chatli MK. Biswas AK. Effect of different levels of baking power on the physic-chemical and sensory attributes of chicken meat caruncles. Haryana Veterinarian 2013;52:17-21.

22. Strange ED, Benedict RC, Smith JL, Swift CE. Evaluation of rapid test for monitoring alteration in meat quality during storage. J Food Protect 1977;40:843-847.

23. Suradkar US. Studies on production and shelf life of chicken nuggets. M.V.Sc. Thesis, submitted to
Maharashtra Animal and Fishery Sciences University, Nagpur, 2008.

24. Vijaykumar KS, Biswas S. Quality andstorage stability of enrobed duck cutlet. J Food. Sci. Tech 2006;43(2):154156.

25. Wilson RB, Pearson AM, Shortand F. Effect of total lipids and phospholipids on warmed over flavor in red and white muscle from several species as measured by TBA analysis. J Agri. Food Chem 1976;24:7-11.

26. Zargar FA, Kumar S, Bhat ZF, Kumar P. Effect of pumpkin on the quality characteristics and storage quality of aerobically packaged chicken sausages. Spinger Plus 2014;3:39. 